\title{
DIVERSITY AND PHENETIC STUDY ON SYCONIUM OF FICUS L. (MORACEAE) FROM KERALA, INDIA REVEALING NATURAL CLASSIFICATION ALONG WITH AN IDENTIFICATION KEY
}

Received January 31, 2021; accepted May 3, 2021

\author{
SREEHARI S. NAIR
}

Research and P. G. Department of Botany, MES Asmabi College, P. Vemballur, Thrissur, Kerala, India. Email:harificus@gmail.com

K. H. AMITHA BACHAN

Research and P. G. Department of Botany, MES Asmabi College, P. Vemballur, Thrissur, Kerala, India. Email: amithabmes@gmail.com

\section{P. J. EBIN}

Department of Botany, Sacred Heart College, Thevara, Cochin, Kerala, India. Email: ebinpj@shcollege.ac.in

\begin{abstract}
NAIR, S. S., BACHAN, K. H. A. \& EBIN, P. J. 2021. Diversity and phenetic study on syconium of Ficus L. (Moraceae) from Kerala, India revealing natural classification along with an identification key. Reinwardtia 20(1): 27-36. - Ficus L. commonly called 'figs' is one of the most complex genera among the angiosperms with its specialised inflorescence called syconium that looks like a fruit. Syconium of 33 species of Ficus reported from Kerala were observed here to develop a novel key, solely based on syconium morphology. Numerical taxonomic methodo logy for syconium morphological characters were standardised, considering 22 characters with 104 character states and analysed using similarity clustering. The floral features of the genus are very much complex and all the existing keys for the species identification relays on both vegetative as well as floral features. Hence, the present key will be practical in use when syconium is the only available part. The numerical analysis of the syconium features well clustered and separated the trees with cauliflorous inflorescence, hemi epiphytic-epiphytic life forms and independent trees similar to the natural classification of the figs as "Atthi, Itthi and Aal", indicating that phenetic analysis using the syconium characters alone provided a grouping similar to the natural grouping based on the habit. Preliminary phylogenetic analysis of figs also provided a similar clustering. This gives an insight into the fact that the separation of figs into these natural groups is reflecting phylogenetic trait. Detailed studies including more morphological traits and molecular analysis could establish the phylogenetic relation of figs in relation to the evolutionary history of climate and vegetation.
\end{abstract}

Key words: Diversity, Ficus, identification key, natural classification, phenetics, syconium.

\begin{abstract}
ABSTRAK
NAIR, S. S., BACHAN, K. H. A. \& EBIN, P. J. 2021. Penelitian keanekaragaman dan fenetik bentuk sikonium Ficus L. (Moraceae) dari Kerala, India, mengungkap klasifikasi alami dan kunci identifikasinya. Reinwardtia 20(1): 27-36. - Ficus L. biasa disebut 'buah ara' adalah salah satu marga paling kompleks di antara angiospermae dengan perbungaan khusus yang disebut sikonium, yang terlihat seperti buah. Sikonium dari 33 jenis Ficus yang dilaporkan dari Kerala diamati di sini untuk mengembangkan kunci baru, hanya berdasarkan morfologi sikonium. Metodologi taksonomi numerik untuk karakter morfologi sikonium distandarisasi, dengan mempertimbangkan 22 karakter dengan 104 status karakter dan dianalisis menggunakan penggugusan keserupaan. Ciri-ciri bunga dari marga sangat kompleks dan semua kunci yang ada untuk identifikasi jenis bergantung pada ciri vegetatif dan juga ciri-ciri bunga. Karenanya, kunci sekarang akan praktis digunakan jika sikonium adalah satu-satunya bagian yang tersedia. Analisis numerik fitur sikonium mengelompok dengan baik dan memisahkan pohon dengan perbungaan kauliflorus, bentuk kehidupan hemi epifitik-epifitik dan pohon independen yang mirip dengan klasifikasi alami buah ara sebagai "Atthi, Itthi dan Aal", menunjukkan bahwa analisis fenetik menggunakan karakter sikonium sendiri memberikan pengelompokan yang mirip dengan pengelompokan alami berdasarkan perawakan. Analisis filogenetik awal dari buah ara juga memberikan pengelompokan yang serupa. Ini memberikan wawasan tentang fakta bahwa pemisahan buah ara ke dalam kelompok alami ini mencerminkan sifat filogenetik. Studi terperinci termasuk lebih banyak sifat morfologi dan analisis molekuler dapat menetapkan hubungan filogenetik buah ara dalam kaitannya dengan sejarah evolusi iklim dan vegetasi.
\end{abstract}

Kata kunci: Fenetik, Ficus, keanekaragaman, klasifikasi alami, kunci identifikasi, sikonium. 


\section{INTRODUCTION}

The genus Ficus L. is the most advanced member in the family Moraceae with a worldwide distribution of about 750 species (Berg \& Corner, 2005; Chaudhary et al., 2012). They are commonly called 'fig' plants. The plant is characterised by the typical hypanthodium inflorescence and the infructescence, a syconium generally referred as 'fig' or 'receptacle'. Fig plants are considered as a keystone species (Vanitharani et al., 2009; Kumar et al., 2011) in many ecosystems, with nutrient rich figs being eaten by reptiles, birds and mammals the year around. In India, the genus has about 115 species including 24 infraspecific taxa (Chaudhary et al., 2012). Thirty one species of figs have been so far reported from Kerala (Sasidharan, 2004). In general, there is a natural classification of the figs (Matthew, 1995) as "Atthi" (trees with cauliflorous inflorescence), "Itthi" (hemi epiphytic and epiphytic trees, stranglers) and "Aal" (independent trees), which were the vernacular names used by Hendrik van Rheede in Hortus Malabariucs (Rheede, 1678).

The presence of minute microscopic flowers within the hypanthodium make the identification of the taxa highly problematic. The keys currently in practice are not solemnly based on syconium characters but rather based on vegetative and floral morphology (Gamble, 1925; Corner, 1965). Development of a key based on syconium features with very detailed diagnosis can make the identification of figs much easier, since the syconium being a very characteristic feature and could be easily collected.

In addition to molecular data, morphological characters can also be used for establishing phylogenetic relationship (Scotland et al., 2003; Wiens, 2004). Consideration of more morphological characters with detailed character states can provide a clear segregation of a genetically related group (Henderson \& Ferreira, 2002; Sonibare et al., 2004; Bolourian \& Pakravan, 2011; Rahman et al., 2013) and this could be closer towards phylogenetic segregation when compared to the traditional morpho taxonomic method.

The present study focuses to provide the diversity of syconium and a key based on the syconium morphology alone for the identification of Ficus species. Also, to understand whether the clustering of figs based on syconium morphology have any similarity with the habit based natural classification of figs into three groups, 'Atthi', 'Itthi' and 'Aal'. Thus, this paper uses the numerical taxonomic techniques for phenetic segregation of figs based on syconium features for developing a strong foundation of syconium based key as well as for testing the similarity with natural classification.
If the natural classification is reflected in the phenetic syconium character segregation, this could be taken as first level confirmation towards the hypothesis that the natural grouping in figs are reflecting the phylogenetic affinity.

\section{MATERIALS AND METHODS}

Extensive field studies were conducted for the collection of specimens. Syconium of the figs were collected and were preserved in FAA solution (Bowles, 2004). Morphological characters of syconium were observed including the vestiture and the images were taken using Coolpix Digital Microscope. The species were identified using regional floras (Gamble, 1925; Sasidharan, 2004) and the identified species were confirmed by herbarium consultation in the herbariums of CALI, KFRI, TBGT and MH. Herbarium specimens and floras were consulted for the analysis of syconium of the species whose fresh materials were unavailable.

The syconium characters were enumerated in a data sheet prepared specifically for syconium features following the terminologies used by Simpson (1953). Multiple samples were analysed for the conformity of the characters. Numerical taxonomic methodology for syconium characters were developed and standardised (Sneath \& Sokal, 1973). Thirty three taxa were diagnosed and entered into the data base with 22 characters covering 104 character states (Table 1). The development of the different character state is based on the range of each character and suitable for entry into a numerical matrix representing 0 and 1 for absence and presence respectively (Fasila et al., 2020). The data was analysed using PAST Software for similarity-based clustering, giving equal weight age for all the character states studied.

A novel key was prepared from the observations of syconium characters and also based on the clustering provided by dendrogram. The habit specifi city of the species was confirmed according to Berg (2003). The similarity clustering dendrogram obtained by analysing 22 morphological characters of syconium was used to test the relatedness of habit based natural grouping in figs with the clustering of figs based on syconium morphology and thereby to understand whether they have any phylogenetic relation.

\section{RESULTS}

Syconium of 33 species of figs studied shows significant character dissimilarity, that are enough to differentiate them into separate species (Fig. 2). Out of the 33 species studied, 27 species had axillary inflorescence and 6 species had cauliflorous inflorescence. Syconium of 12 species were sessile 


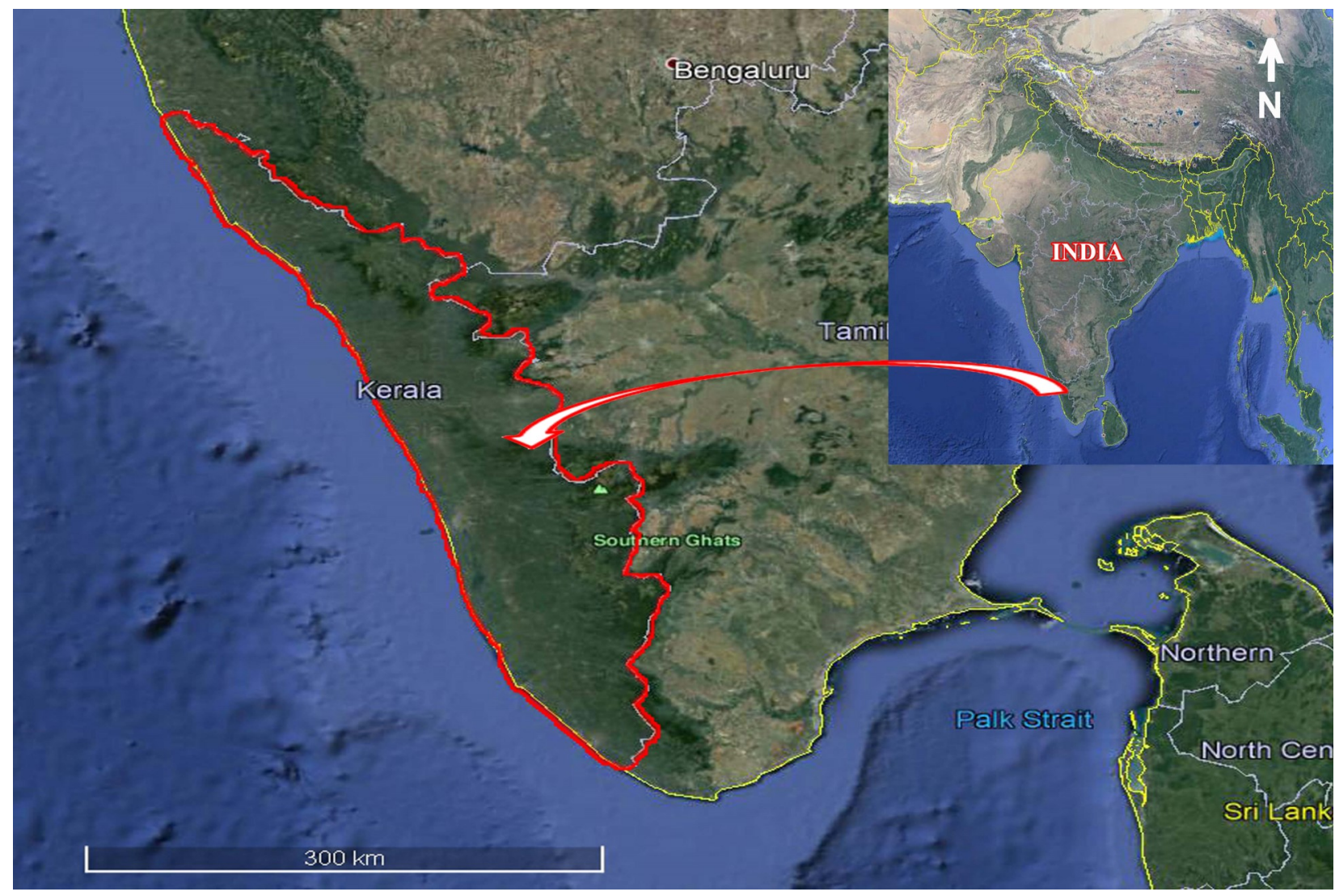

Fig. 1. Study area, Kerala State, India.

and 21 were pedunculate. Among the 12 species with sessile syconium, 10 species were having outer bracts, while two species were devoid of outer bracts. Within the 21 pedunculate species, 15 species had outer bracts and 6 species lack outer bracts (Fig. 3). Vestiture on the surface of the syconium were characteristic and were consistent in all the species studied. Glabrous or hairy vestiture of the syconium were also used to separate the species.

Numerical taxonomic analysis of the syconium characters also showed species level separation with significant similarity and dissimilarity coefficient. The maximum dissimilarity was observed for F. auriculata Lour (44\%). Ficus rigida var. bracteata (Corner) Bennet \& F. superba Miq and F. microcarpa L.f \& F. binnendijkii (Miq.) Miq. were the most similar species with a $92 \%$ similarity.

The dendrogram developed through similarity clustering using PAST software is given (Fig. 4). The species were clustered into three major groups based on the similarity of syconium morphology. Habit preference of the species plotted on the dendrogram and it showed a similar grouping pattern with the syconium morphology-based clustering.

\section{DISCUSSION}

The morphological features of the syconium were well segregated providing a syconium based identification key for 33 species. This could be very useful in practise, since the syconium is the most available part of a fig during any kind of field study. This can help field botanists as well as ecologists and people from other disciplines. The numerical analysis provided more clarity for preparing such a practical key based on syconium features.

Natural grouping in figs based on habit divides them into three groups as 'Atthi, Itthi and Aal' in Malayalam, which include the trees with cauliflorous inflorescence, hemi epiphytic-epiphytic life forms and independent trees respectively. Similarity clustering based on 104 character states of the syconium morphology alone separated the species significantly and also clustered them into three groups similar to the natural grouping based on habit, strengthening relatedness between clustering based on syconium morphology and natural grouping. The only exceptions in the clustering were $F$. superba and $F$. hispida, two cauliflorous species ware grouped along with the independent 
Table 1. Character and character states of Ficus species studied.

\begin{tabular}{|c|c|c|}
\hline S1. No. & Character & Character States \\
\hline 1 & Inflorescence position & Axillary, cauliflorous \\
\hline 2 & Inflorescence clustering & Solitary, paired, clustered \\
\hline 3 & Basal bracts & Present, absent \\
\hline 4 & Syconium length maximum & $\begin{array}{l}1-10 \mathrm{~mm}, 11-20 \mathrm{~mm}, 21-30 \mathrm{~mm}, 31-40 \mathrm{~mm}, 41-50 \\
\mathrm{~mm}, 51-60 \mathrm{~mm}, 61-70 \mathrm{~mm}, 71-80 \mathrm{~mm}, 81-90 \mathrm{~mm}, 91- \\
100 \mathrm{~mm}\end{array}$ \\
\hline 5 & Syconium length minimum & $\begin{array}{l}1-10 \mathrm{~mm}, 11-20 \mathrm{~mm}, 21-30 \mathrm{~mm}, 31-40 \mathrm{~mm}, 41-50 \\
\mathrm{~mm}, 51-60 \mathrm{~mm}\end{array}$ \\
\hline 6 & Syconium width maximum & $\begin{array}{l}1-10 \mathrm{~mm}, 11-20 \mathrm{~mm}, 21-30 \mathrm{~mm}, 31-40 \mathrm{~mm}, 41-50 \\
\mathrm{~mm}, 51-60 \mathrm{~mm}, 61-70 \mathrm{~mm}\end{array}$ \\
\hline 7 & Syconium width minimum & $\begin{array}{l}1-10 \mathrm{~mm}, 11-20 \mathrm{~mm}, 21-30 \mathrm{~mm}, 31-40 \mathrm{~mm}, 41-50 \\
\mathrm{~mm}\end{array}$ \\
\hline 8 & Syconium shape & Obovoid, globose, turbinate, oblong, ovoid \\
\hline 9 & Syconium pubescence & Glabrous, hairy, hairy near ostiole \\
\hline 10 & Syconium texture & $\begin{array}{l}\text { Glabrous, pubescent, pilose, scars, scabrid, strigose, } \\
\text { puberulent, tomentose }\end{array}$ \\
\hline 11 & Peduncle & Present, absent \\
\hline 12 & Peduncle length maximum & $1-10 \mathrm{~mm}, 11-20 \mathrm{~mm}, 21-30 \mathrm{~mm}, 31-40 \mathrm{~mm}$ \\
\hline 13 & Peduncle length minimum & $1-10 \mathrm{~mm}, 11-20 \mathrm{~mm}, 21-30 \mathrm{~mm}, 31-40 \mathrm{~mm}$ \\
\hline 14 & Peduncle width maximum & $1-5 \mathrm{~mm}, 6-10 \mathrm{~mm}, 11-15 \mathrm{~mm}$ \\
\hline 15 & Peduncle width minimum & $0-1.0 \mathrm{~mm}, 1.1-2.0 \mathrm{~mm}, 2.1-3.0 \mathrm{~mm}, 3.1-4.0 \mathrm{~mm}$ \\
\hline 16 & Peduncle shape & Terete, angular \\
\hline 17 & Peduncle pubescence & Glabrous, hairy \\
\hline 18 & Peduncle texture & $\begin{array}{l}\text { Glabrous, pubescent, pilose, scars, scabrid, strigose, } \\
\text { puberulent, villous }\end{array}$ \\
\hline 19 & Syconium colour at young stage & Green, pale green \\
\hline 20 & Syconium colour on maturity & $\begin{array}{l}\text { Green, dark green, pale brown, yellow, pale yellow, } \\
\text { orange, pale red, purple, white, grey }\end{array}$ \\
\hline 21 & Syconium colour on ripening & $\begin{array}{l}\text { Green, dark green, pale brown, yellow, pale yellow, } \\
\text { orange, pale red, purple, brown }\end{array}$ \\
\hline 22 & Lenticels & Present, absent \\
\hline
\end{tabular}



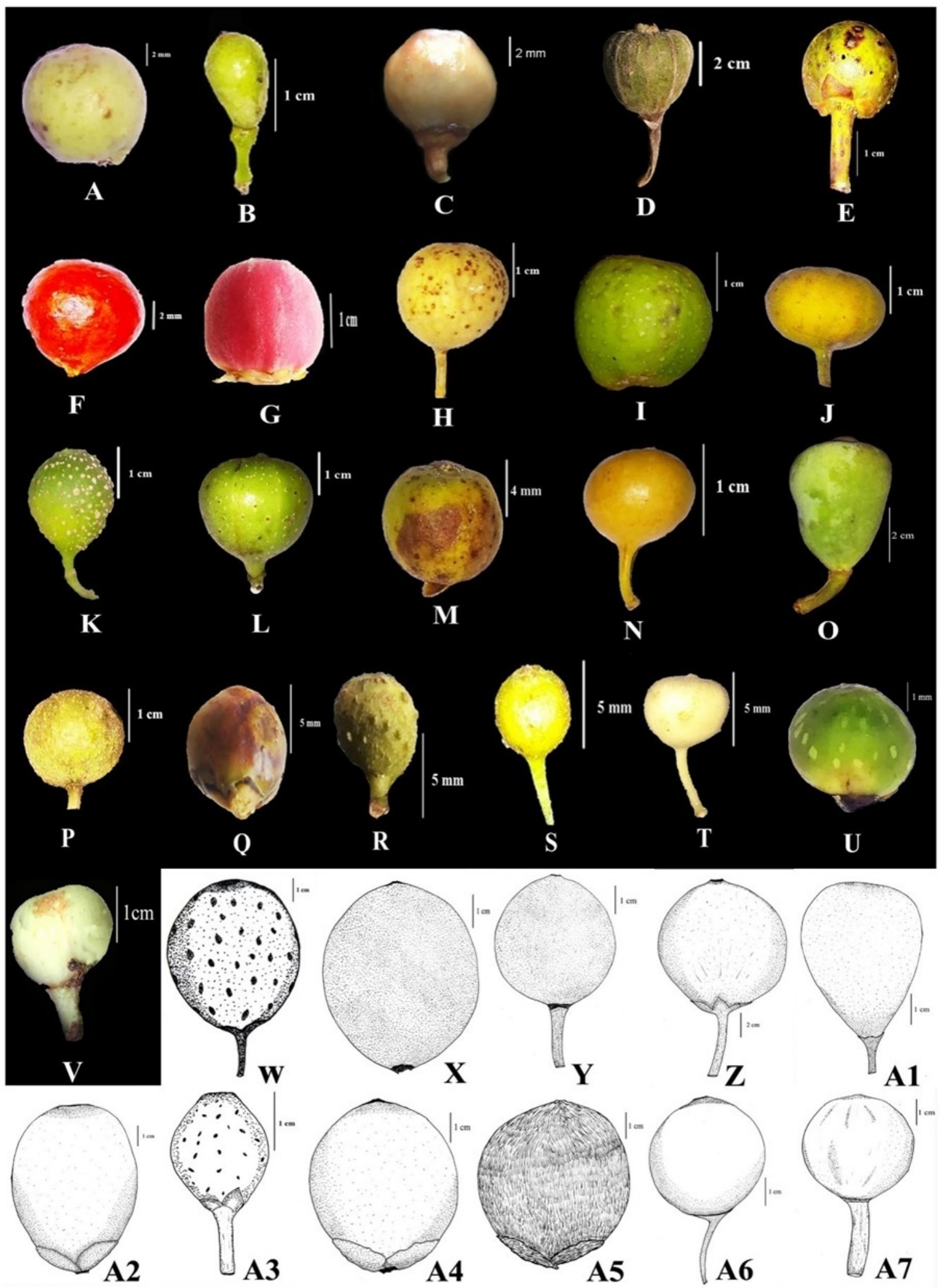

Fig. 2. Syconium of figs. A. F. amplissima. B. F. anamalayana. C. F. arnottiana. D. F. auriculata. E. F. beddomei. F. F. benjamina. G. F. benghalensis. H. F. callosa. I. F. drupacea. J. F. asperata. K. F. heterophylla. L. F. hispida. M. F. microcarpa. N. F. nervosa. O. F. pumila. P. F. racemosa. Q. F. religiosa. R. F. talbotii. S. F. tinctoria ssp. gibbosa. T. F. tinctoria ssp. parasitica. U. F. tsjahela. V. F. virens. W. F. amplocarpa. X. F. binnendijkii. Y. F. caulocarpa. Z. F. costata. A1. F. dalhousiae. A2. F. elastica. A3. F. guttata. A4. F. krishnae. A5. F. mollis. A6. F. rigida var. bracteata. A7. F. superba. 


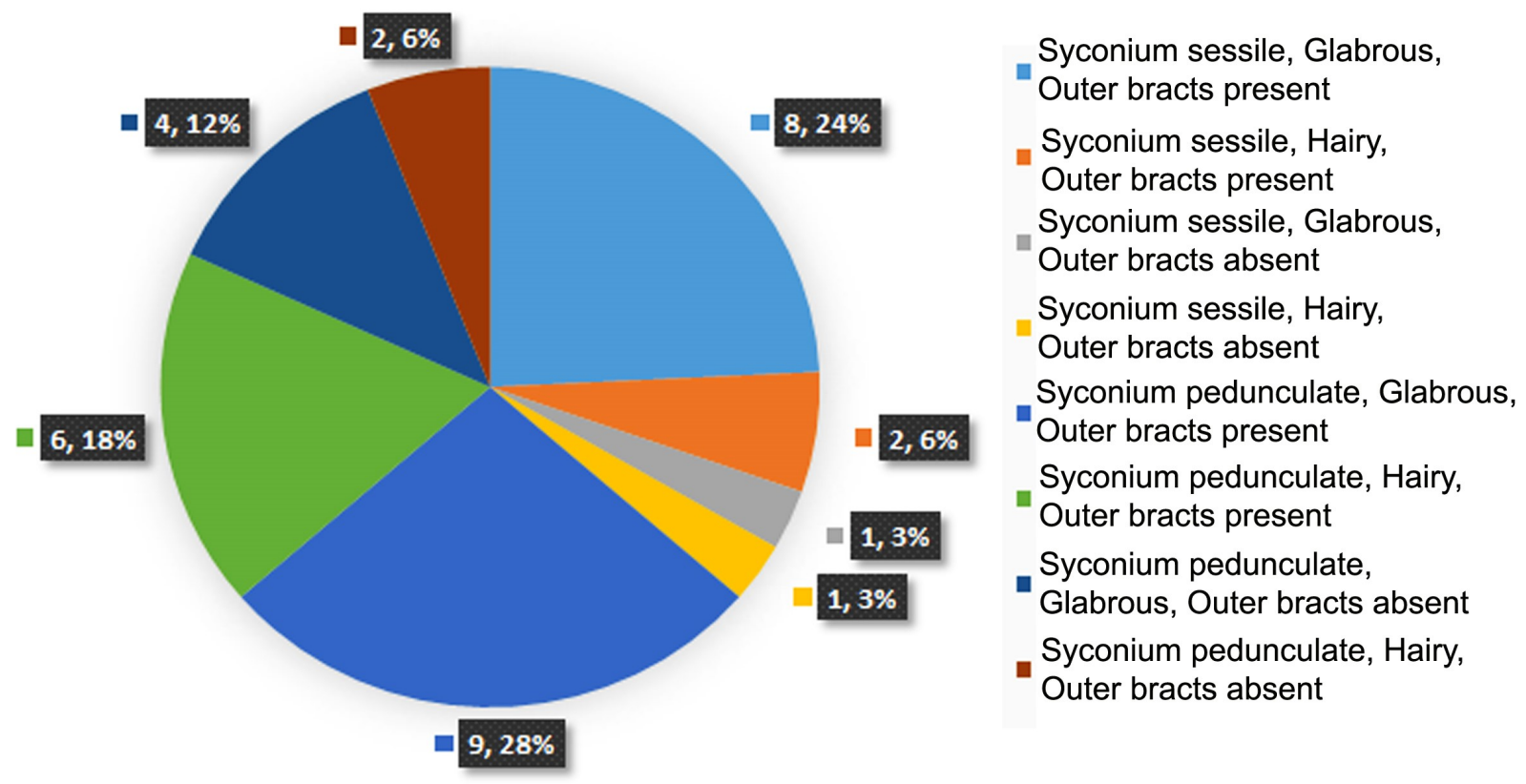

Fig. 3. Diversity of the syconium.

\section{Syconium Based Key for the Identification of Ficus species}

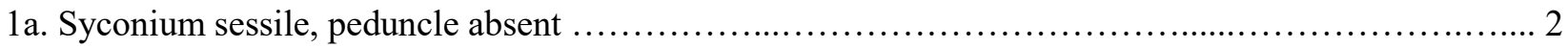

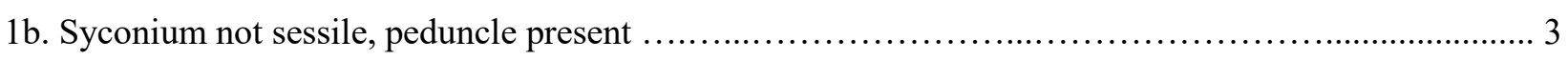

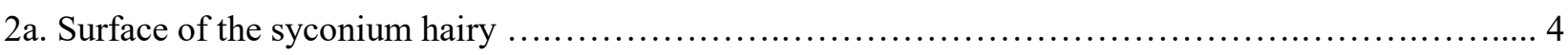

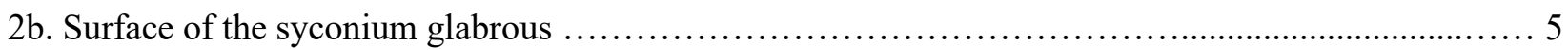

4a. Receptacles paired, surface with puberulent hairs, basal bracts absent .......................... F. krishnae

4b. Receptacles clustered, surface with pubescent or tomentose hairs, basal bracts present .................. 6

6a. Figs with pubescent hairs, $1.5-2.5 \mathrm{~cm}$ in size, red coloured on ripening ............. F. benghalensis

6b. Figs with tomentose hairs, $0.8-1.0 \mathrm{~cm}$ in size, brown coloured on ripening ................. F. mollis

5a. Surface of the syconium with scars, syconium solitary in arrangement ..................... F. talbotii

5 b. Surface of the syconium glabrous without scars, syconium not solitary in arrangement,

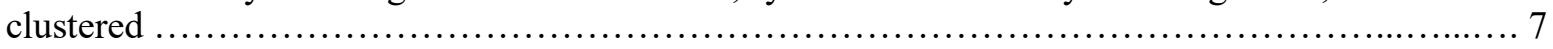

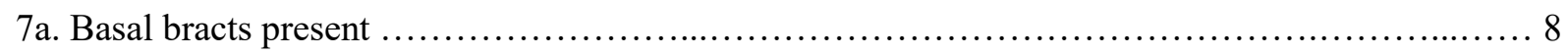

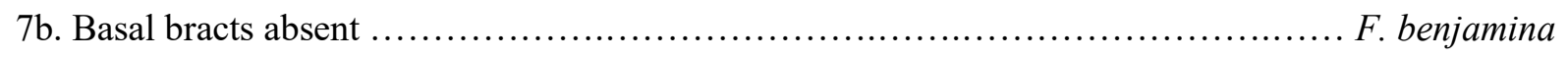

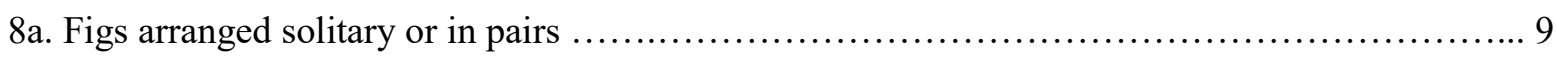

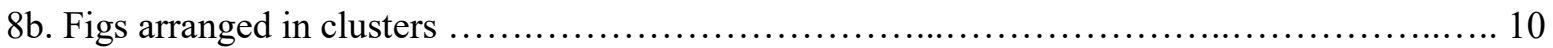

9a. Syconium obovoid in shape, arranged solitary ..............................F. amplissima

9b. Syconium not obovoid in shape, arranged in pairs .................................... 11

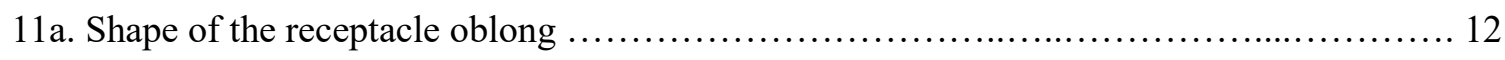

$11 \mathrm{~b}$. Shape of the receptacle not oblong, globose or ovoid .............................. 13

12a. Figs up to $4 \mathrm{~cm}$, red coloured on ripening .............................. F. drupacea

12b. Figs up to $1.5 \mathrm{~cm}$, yellow coloured on ripening ................................... F. elastica

13a. Receptacle globose in shape, $0.8-1.0 \mathrm{~cm}$ in size, orange coloured on ripening ............................................................... Ficrocarpa

13b. Receptacle ovoid in shape, $0.3-0.5 \mathrm{~cm}$ in size, red coloured on ripening . 
10a. Syconium $0.4-1.0 \mathrm{~cm}$ in size, red coloured on ripening F. religiosa

$10 \mathrm{~b}$. Syconium $0.5-0.6 \mathrm{~cm}$ in size, pale brown coloured on ripening F. tsjakela

3a. Figs cauliflorous 14

3b. Figs axillary

14a. Receptacles in pairs, arising from long hanging racemes, rarely axillary F. hispida

14b. Receptacles in clusters, arising from the main trunk only 16

16a. Turbinate shaped syconium, surface of the syconium hairy. F. auriculata

16b. Globose shaped syconium, surface of the syconium glabrous 17

17a. Figs less than $1.5 \mathrm{~cm}$ across, purple coloured in ripening F. superba

$17 \mathrm{~b}$. Figs above $2.0 \mathrm{~cm}$ across, red coloured in ripening 18

18a. Receptacles in clusters of many, on long racemes (up to $15 \mathrm{~cm}$ ) ................. F. racemosa

$18 \mathrm{~b}$. Receptacles in clusters of few, not on long racemes

19a. Figs large, $3.0-6.5 \mathrm{~cm}$ in size, peduncle up to $1.0 \mathrm{~cm}$ in length, mature figs without ooze of resin .................................................................. . amplocarpa

19b. Figs small, up to $2.5-3.5 \mathrm{~cm}$ in size, peduncle above $1.0 \mathrm{~cm}$ in length, mature figs with ooze of resin ...

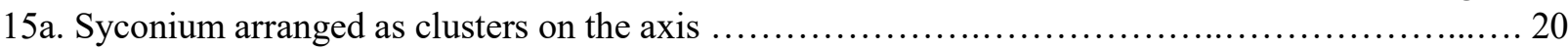

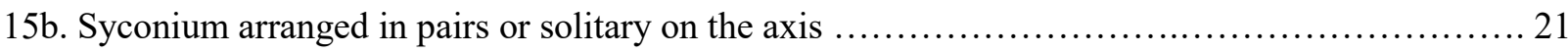

20a. Peduncle and figs hairy, peduncle up to $0.2-0.4 \mathrm{~cm}$ long ......................... F. caulocarpa

20b. Peduncle and figs glabrous, peduncle up to $0.1-0.2 \mathrm{~cm}$ long .................... F. arnottiana

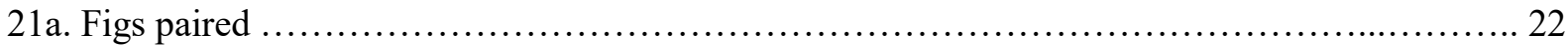

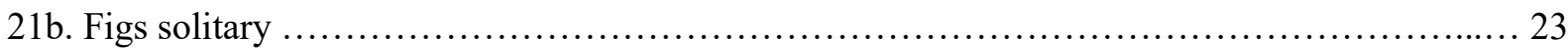

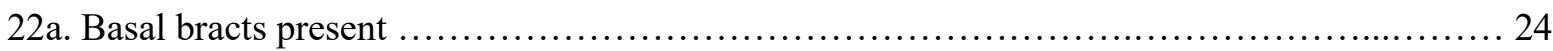

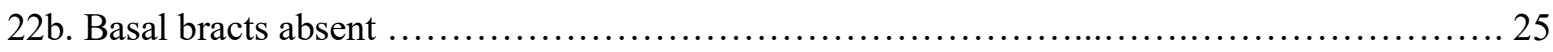

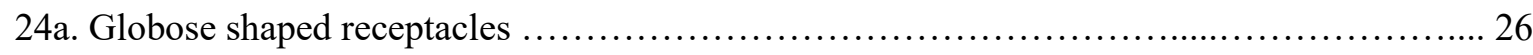

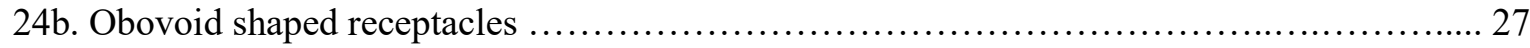

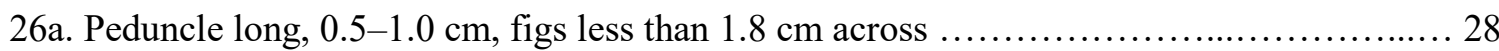

26b. Peduncle short, $0.1-0.3 \mathrm{~cm}$, figs $2.0 \mathrm{~cm}$ and above ................................ F. virens

28a. Receptacles $1.2-1.6 \mathrm{~cm}$ in size, peduncle $0.5-0.8 \mathrm{~cm}$ long, yellow-red coloured on

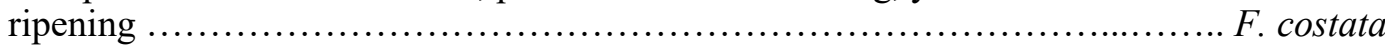

28b. Receptacles $0.8-1.2 \mathrm{~cm}$ in size, peduncle $0.5-1.0 \mathrm{~cm}$ long, pale brown-purple coloured on ripening ........................................ F. rigida var. bracteata

27a. Syconium above $3.5 \mathrm{~cm}$, surface glabrous with scars, peduncle angular in shape ...... ................................................................................... beddomei

27b. Syconium below $2.5 \mathrm{~cm}$, surface hairy without scars, peduncle terete in shape ............. 29

29a. Figs and peduncle hairy, figs $1.0-1.6 \mathrm{~cm}$ across, peduncle $0.8-1.0 \mathrm{~cm} \ldots \ldots . . F$. dalhousiae

$29 \mathrm{~b}$. Figs hairy near ostiole and peduncle glabrous, figs $1.6-2.3 \mathrm{~cm}$ across, peduncle

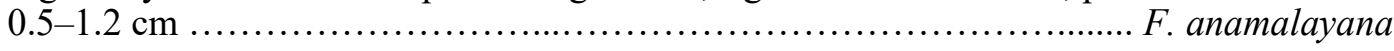

25a. Length of the peduncle above $1.0 \mathrm{~cm}$, receptacles red coloured on ripening ...F. exasperata

$25 \mathrm{~b}$. Length of the peduncle below $0.8 \mathrm{~cm}$, receptacles yellow coloured on ripening 30

30a. Surface of the syconium hairy, below $0.8 \mathrm{~cm}$ in size, peduncle $0.4-0.6 \mathrm{~cm}$ in length F. tinctoria ssp. gibbosa

$30 \mathrm{~b}$. Surface of the syconium glabrous, above $1.0 \mathrm{~cm}$ in size, peduncle $0.5-1.0 \mathrm{~cm}$ in length F. tinctoria ssp. parasitica

23a. Receptacle obovoid in shape, hairy, with basal bracts F. pumila

23b. Receptacle globose in shape, glabrous, without basal bracts 31

31a. Syconium with scars on the surface, $2.8-3.5 \mathrm{~cm}$ across, peduncle hairy $\ldots \ldots \ldots . F$. heterophylla

31b. Syconium without scars on the surface, glabrous, below $3.0 \mathrm{~cm}$ across, peduncle glabrous.. 32

32a. Receptacles $2.5 \mathrm{~cm}$ and above, peduncle length above $1.0 \mathrm{~cm}$ F. callosa

$32 \mathrm{~b}$. Receptacles below $2.0 \mathrm{~cm}$, peduncle length $0.8-1.0 \mathrm{~cm}$ F. nervosa 


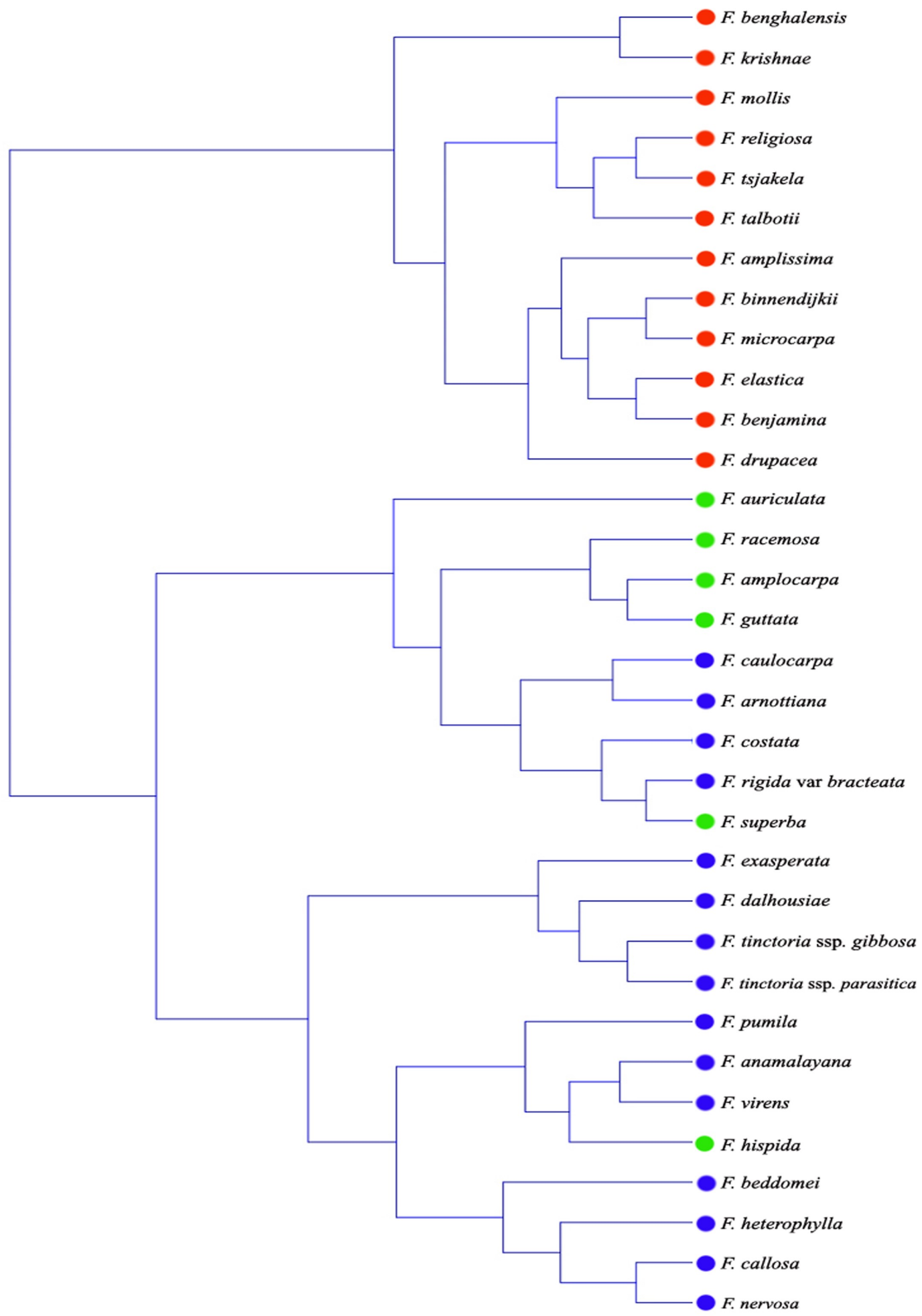

Fig. 4. Dendrogram showing the clustering of figs based on syconium morphology and habit preference. 
trees. Ficus superba might have grouped among them due to the close similarity in the syconium morphology with other species in the group. Ficus hispida shows cauliflorous inflorescence as well as axillary inflorescence. Along with this, the close similarity in syconium morphological characters could be the reason for the exceptional clustering of this species with other members. Phylogenetic studies on figs also provided a similar grouping (Sreehari \& Bachan, 2020).

Morphometric studies were used to establish the genetic relatedness in many genera (Rahman et al., 2013). Since the phenetic analysis of the syconium and preliminary phylogenetic analysis shows a clustering, similar to the natural grouping of figs, this could be taken as first level confirmation towards the hypothesis that the natural grouping in figs is reflecting the phylogenetic affinity.

\section{CONCLUSION}

The syconium based numerical analysis showed that the morphological variations in syconium characters alone is significant to separate the species. Hence, the syconium morphology-based identification key will be practical in use, even when the syconium is the only available part. The syconium morphology-based clustering was much similar to the natural grouping of figs into trees with cauliflorous inflorescence, hemi epiphyticepiphytic life forms and independent trees, indicating phylogenetic affinity. Detailed phenetic analysis incorporating more morphological characters, molecular studies including a greater number of taxa and their ecological association within a geographical enclosure can provide more light on the phylogeny of figs in relation to the evolutionary history of climate and vegetation.

\section{ACKNOWLEDGEMENTS}

We are grateful to the Department of Botany, MES Asmabi College, P. Vemballur and Sacred Herat College, Thevara, for providing the facilities to carry out the work. The authors are thankful to the curators of CALI, KFRI, TBGT and MH for the services provided for the completion of the study.

\section{REFERENCES}

BERG, C. C. 2003. Flora Malesiana precursor for the treatment of Moraceae 1: the main subdivision of Ficus: the subgenera. Blumea 48(1): $166-177$.
BERG, C. C. \& CORNER, E. J. H. 2005. Moraceae: Ficus. Flora Malesiana Series I (Seed Plants) 17. Pp. 1-730.

BOLOURIAN, S. \& PAKRAVAN, M. 2011. A morphometric study of the annual species of Alyssum (Brassicaceae) in Iran based on their macro- and micromorphological characters. Phytologia Balcanica 17(3): 283-289.

BOWLES, J. M. 2004. Guide to plant collection and identification. UWO Herbarium workshop on plant collection and identification. $23 \mathrm{pp}$.

CHAUDHARY, L. B., SUDHAKAR, J. V., KUMAR, A., BAJPAI, O. \& TIWARI, R. 2012. Synopsis of the genus Ficus L. (Moraceae) in India. Taiwania 57(2): 193-216.

CORNER, E. J. H. 1965. Check List of Ficus in Asia and Australasia with keys to identification. Gard. Bull. Sing. 21: 1-186.

FASILA, P. K., BACHAN, A. K. H., GIRIJA, T. P. \& PRADEEP, A. K. 2020. Cryptocarya sheikelmudiyana (Lauraceae), a new species from the Western Ghats in Kerala, India. Taiwania 65(3): 265-271.

GAMBLE, J. S. 1925. Flora of the Presidency of Madras. Vol. 3. Adlard \& Son. Ltd., London. Pp. 1351-1371.

HENDERSON, A. \& FERREIRA, E. 2002. A morphometric study of Synechanthus (Palmae). Systematic Botany 27(4): 693-702.

KUMAR, A., BAJPAI, O., MISHRA, A. K., SAHU, N., BEHERA, S. K. \& CHAUDHARY, L. B. 2011. Assessment of diversity in the genus Ficus L. (Moraceae) of Katerniaghat Wildlife Sanctuary, Uttar Pradesh, India. American Journal of Plant Sciences 2(1): 7892.

MATTHEW, K. M. 1995. An Excursion Flora of Central Tamil Nadu, India. CRC Press.

RAHMAN, M. O., RAHMAN, M. Z. \& BEGUM, A. 2013. Numerical taxonomy of the genus Senna Mill. from Bangladesh. Bangladesh Journal of Plant Taxonomy 20(1): 77-83.

RHEEDE TOT DRAAKESTEIN, H. A. VAN. 1678. Hortus Indicus Malabaricus. Vol. 1. Amsterdam: J. van Someren \& J. van Dyck. DOI: 10.5962/bhl.title.707 pp.

SASIDHARAN, N. \& SIVARAJAN, V. V. 2004. Biodiversity Documentation of Kerala. Part 6. KFRI Hand Book.

SCOTLAND, R. W., OLMSTEAD, R. G. \& BENNETT, J. R. 2003. Phylogeny reconstruction: the role of morphology. Syst. Biol. 52 (4): 539-548. DOI: $10.1080 / 10635150390223613$.

SIMPSON, M. G. 1953. Plant Systematics. Elsevier. Inc.

SNEATH, P. H. A. \& SOKAL, R. R. 1973. Numerical Taxonomy. Freeman and Company, San Francisco, USA. 
SONIBARE, M. A., JAYEOLA, A. A. \& EGUNYOMI, A. 2004. A morphometric analysis of the genus Ficus Linn. (Moraceae). African Journal of Biotechnology 3(4): 229-235.

SREEHARI, S. N. \& BACHAN, A. K. H. 2020. Phylogenetic study on the genus Ficus L. (Moraceae) in Kerala using ITS sequences as molecular marker. Meridian 9(1): 34-37.
VANITHARANI, J., BHARATHI, B. K., MARGARET, I. V., MALLESHAPPA, H., OJHA R. K. \& NAIK, K. G. A. 2009. Ficus diversity in Southern Western Ghats: a boon for biodiversity conservation. Journal of Theoretical Experimental Biology 6(1): 69-79.

WIENS, J. J. 2004. The role of morphological data in phylogeny reconstruction. Syst. Biol. 53(4): 653-661. DOI: 10.1080/10635150490472959. 